\title{
Construction of industrial Saccharomyces cerevisiae strains for the efficient consolidated bioprocessing of raw starch
}

\author{
Rosemary A. Cripwell ${ }^{1}$ (B), Shaunita H. Rose ${ }^{1}$, Lorenzo Favaro ${ }^{2}$ (D) and Willem H. van Zyl ${ }^{1 *}$ (i)
}

\begin{abstract}
Background: Consolidated bioprocessing (CBP) combines enzyme production, saccharification and fermentation into a one-step process. This strategy represents a promising alternative for economic ethanol production from starchy biomass with the use of amylolytic industrial yeast strains.

Results: Recombinant Saccharomyces cerevisiae Y294 laboratory strains simultaneously expressing an a-amylase and glucoamylase gene were screened to identify the best enzyme combination for raw starch hydrolysis. The codon optimised Talaromyces emersonii glucoamylase encoding gene (temG_Opt) and the native T. emersonii a-amylase encoding gene (temA) were selected for expression in two industrial S. cerevisiae yeast strains, namely Ethanol Red ${ }^{\mathrm{TM}}$ (hereafter referred to as the ER) and M2n. Two $\delta$-integration gene cassettes were constructed to allow for the simultaneous multiple integrations of the temG_Opt and temA genes into the yeasts' genomes. During the fermentation of $200 \mathrm{~g} \mathrm{I}^{-1}$ raw corn starch, the amylolytic industrial strains were able to ferment raw corn starch to ethanol in a single step with high ethanol yields. After $192 \mathrm{~h}$ at $30^{\circ} \mathrm{C}$, the S. cerevisiae ERT12 and M2n T1 strains (containing integrated temA and temG_Opt gene cassettes) produced 89.35 and $98.13 \mathrm{~g} \mathrm{I}^{-1}$ ethanol, respectively, corresponding to estimated carbon conversions of 87 and $94 \%$, respectively. The addition of a commercial granular starch enzyme cocktail in combination with the amylolytic yeast allowed for a 90\% reduction in exogenous enzyme dosage, compared to the conventional simultaneous saccharification and fermentation (SSF) control experiment with the parental industrial host strains.
\end{abstract}

Conclusions: A novel amylolytic enzyme combination has been produced by two industrial S. cerevisiae strains. These recombinant strains represent potential drop-in CBP yeast substitutes for the existing conventional and raw starch fermentation processes.

Keywords: Consolidated bioprocessing, Biofuels, Industrial yeast, Amylases, Raw corn starch, Talaromyces emersonii

\section{Background}

Starch is a readily available renewable material found in most regions of the world [1]. There are numerous types of starchy biomass that represent attractive substrates for bioethanol production, namely corn (maize), wheat, oats, rice, potato and cassava [2]. For decades, amylolytic enzymes from various microbial sources have been used in starch based processes, which has led to amylases

\footnotetext{
*Correspondence: whvz@sun.ac.za

${ }^{1}$ Department of Microbiology, Stellenbosch University, Private Bag X1, Matieland 7602, South Africa

Full list of author information is available at the end of the article
}

being among the most important enzymes used for industrial applications [3]. However, only a limited number of fungal and bacterial strains meet the criteria for commercial amylase production. Therefore, new microorganisms are continuously screened for amylase activity, especially for applications in the biofuel industry.

The conventional process for the conversion of starch to ethanol requires a heat-intensive liquefaction step together with thermostable $\alpha$-amylases to gelatinise the starch, followed by saccharification with a glucoamylase. The high temperatures required for the initial processes usually account for approximately $30-40 \%$ of the total energy required for ethanol production [4]. An 
alternative to this is a cold hydrolysis process at temperatures below the onset of starch gelatinisation $\left(65^{\circ} \mathrm{C}\right.$ for corn) [5]. Benefits of this process include reduced energy requirements and higher nutritional content for the distiller's dried grains with solubles (DDGS) [6]. DDGS are produced in large quantities during bioethanol production and represent a valuable ingredient for livestock feed [7].

Consolidated bioprocessing (CBP) using a single organism combines enzyme production, substrate hydrolysis and glucose fermentation into a one-step process for bioethanol production at low temperatures [8]. This technology has developed rapidly over the last decade and is a promising approach for the economic production of biofuel from lignocellulosic and starchy feedstocks [9]. However, CBP has not yet been implemented on a commercial scale with the main challenge being the availability of an ideal host microorganism that can express suitable enzymes and have a high fermentation capacity [10]. CBP would simplify operational processes (e.g. number of control steps and reaction vessels) and, therefore, reduce maintenance and production costs. The comprehensive review on consolidated bioprocessing systems [9] highlighted different CBP strategies, diversity in the substrate types, as well as the organisms involved in fermenting the sugars.

Currently, no industrial process uses a recombinant amylolytic yeast strain for starch CBP that produces both an $\alpha$-amylase and glucoamylase, but the commercial production of granular starch hydrolysing enzyme (GSHE) cocktails has allowed for the development of simultaneous saccharification and fermentation (SSF) processes (at lower temperatures) for ethanol production from starchy substrates $[4,6]$. An existing market is available for a drop-in CBP yeast that is able to simultaneously express raw starch $\alpha$-amylase and glucoamylase encoding genes for complete starch hydrolysis. One of the main challenges remains the simultaneous production of these enzymes exhibiting high substrate affinities and specific activity [11].

It is estimated that the use of raw starch hydrolysing enzymes for ethanol production reduces energy costs by 10-20\% [5]. Currently, the commercially available GSHE cocktails from DuPont Industrial Biosciences (DuPontDanisco, Itasca, USA) hydrolyse raw starch at low temperatures $\left(48{ }^{\circ} \mathrm{C}\right.$ is recommended for SSF), while POET (Sioux Falls, South Dakota, USA) use a patented blend of Novozymes enzymes (POET BPX technology) in an SSF process [12]. Glucoamylase producing Saccharomyces cerevisiae strains such as TransFerm ${ }^{\circledR}$ (Lallemand, Montreal, Canada) and Innova ${ }^{\circledR}$ Drive (Novozymes, Copenhagen, Denmark) are commercially available (http://www. ethanoltech.com/transferm and https://www.novozymes. com/en/advance-your-business/bioenergy/innovadrive, respectively). However, these recombinant yeast strains lack an $\alpha$-amylase enzyme required for starch liquefaction $[10,13]$ and are therefore only semi-CBP yeast. Recently, amylase corn (corn containing endogenous $\alpha$-amylase) in combination with a "superior" glucoamylase producing yeast strain has been used to improve ethanol yields [14], but this process still requires high temperatures $\left(85^{\circ} \mathrm{C}\right)$ for starch gelatinisation.

In this study, novel amylase gene combinations were cloned and expressed in the S. cerevisiae Y294 laboratory strain and the amylolytic transformants were screened for their raw starch fermenting ability. Subsequently, the enzyme combination that best hydrolysed raw corn starch was expressed in two industrial $S$. cerevisiae strains, namely Ethanol Red ${ }^{\mathrm{TM}}$ which is one of the most widely used yeast strains for first-generation bioethanol production [15] and M2n, which is a South African distillery yeast [16]. Gene integration and the acetamide selection method were used for the engineering of the industrial yeast strains. The use of the acetamidase encoding gene $(a m d S)$ as a dominant marker enabled the selection of recombinant prototrophic strains on acetamide [17], which replaced the conventional selection method that requires antibiotics. The industrial amylolytic strains were evaluated at high solids loadings under two different fermentation temperatures and were able to convert raw corn starch into ethanol, with a yield close to the theoretical maximum.

\section{Results and discussion}

\section{Cloning and recombinant amylase expression in $S$. cerevisiae Y294}

Starch-rich biomass is currently the main substrate for bioethanol production in the United States [18] and it can be efficiently hydrolysed using $\alpha$-amylase and glucoamylase enzymes [19]. Following the identification of novel amylase candidates with superior hydrolytic activity [20] several plasmids were designed to simultaneously express two amylase genes, namely an $\alpha$-amylase and glucoamylase gene combination, under the transcriptional control of the ENO1 promoter and terminator sequences. The episomal plasmids were introduced into the S. cerevisiae Y294 laboratory strain to obtain amylolytic yeasts suitable for the one-step conversion of raw corn starch flour (henceforth referred to as raw corn starch) to ethanol. The recombinant strains (listed in Table 1) were evaluated for their ability to hydrolyse raw corn starch at a high substrate loading $\left(200 \mathrm{~g} \mathrm{l}^{-1}\right.$ corn starch) and ferment the resulting glucose to ethanol. Six different recombinant amylolytic strains, expressing novel gene combinations, were compared to the previously constructed S. cerevisiae Y294[AmyA-GlaA] strain 
Table 1 Strains and plasmids used in this study

\begin{tabular}{|c|c|c|}
\hline Strains and plasmids & Genotype & References/source \\
\hline E. coliDH5a & $\begin{array}{l}\text { supE44 } \triangle l a c U 169 \text { ( } \varphi 80 \text { lacZDM15) hdR17 recA1 endA1 gyrA96 thi-1 } \\
\text { relA1 }\end{array}$ & [43] \\
\hline \multicolumn{3}{|l|}{ S. cerevisiae strains } \\
\hline Y294 & a leu2-3,112 ura3-52 his3 trp 1-289 & ATCC 201160 \\
\hline Y294[AmyA-GlaA] & $\begin{array}{l}\text { URA3 ENO1 } 1_{\mathrm{p}}-\mathrm{glaA}-E N O 1_{\mathrm{T}} ; \\
\text { ENO1 }\end{array}$ & [19] \\
\hline Y294[GlaA-TemA] & $\begin{array}{l}\text { URA3 ENO1 } 1_{\mathrm{p}}-\mathrm{glaA}-E N O 1_{\mathrm{T}} \\
\text { ENO1 } \\
\text {-temA-ENO1 }\end{array}$ & This study \\
\hline Y294[TemG_Opt-AmyA] & 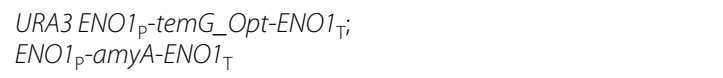 & This study \\
\hline Y294[TemG_Opt-AteA] & $\begin{array}{l}\text { URA3 ENO1 } 1_{\mathrm{p}} \text {-temG_Opt-ENO1 } 1_{\mathrm{T}} \\
\text { ENO1 }\end{array}$ & This study \\
\hline Y294[TemG_Opt-ApuA] & $\begin{array}{l}\text { URA3 ENO1 } 1_{\mathrm{p}} \text {-temG_Opt-ENO1 } 1_{\mathrm{T}} \\
\text { ENO1 }\end{array}$ & This study \\
\hline Y294[TemG_Opt-TemA] & $\begin{array}{l}\text { URA3 ENO1 } 1_{\mathrm{p}} \text {-temG_Opt-ENO1 }{ }_{T} ; \\
\text { ENO1 }\end{array}$ & This study \\
\hline Y294[TemG_Opt-TemA_Opt] & 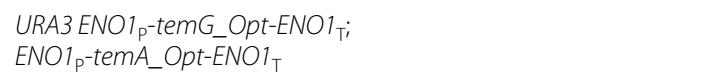 & This study \\
\hline Y294[amdSYM] & URA3 TEF - -amdS-TEF & This study \\
\hline$E R^{a}$ & MATa/a prototroph & Fermentis, Lesaffre, France \\
\hline$M 2 n$ & MATa/a prototroph & [16] \\
\hline$E R T 1^{b}$ & $\begin{array}{l}\text { S-integration of ENO1 } 1_{\mathrm{p}} \text {-temG_Opt-ENO1 } 1_{\mathrm{T}} \\
\text { ENO1 }\end{array}$ & This study \\
\hline $\mathrm{ERT} 12^{\mathrm{b}}$ & 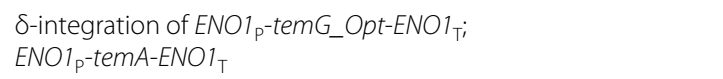 & This study \\
\hline$M 2 n T 1^{b}$ & $\begin{array}{l}\text { S-integration of ENO1 } 1_{\mathrm{p}} \text {-temG_Opt-ENO1 }{ }_{\mathrm{T}} \\
\text { ENO1 }\end{array}$ & This study \\
\hline$M 2 n T 2^{b}$ & 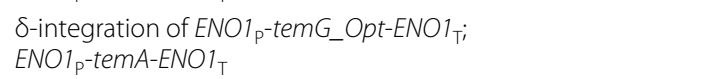 & This study \\
\hline \multicolumn{3}{|l|}{ Plasmids } \\
\hline $\mathrm{yBBH} 1$ & bla URA3 ENO1 $1_{\mathrm{P}}-E N O 1_{\mathrm{T}}$ & [49] \\
\hline yBBH1-AmyA & bla URA3 ENO1 $1_{\mathrm{p}}$-amyA-ENO1 $1_{\mathrm{T}}$ & [19] \\
\hline yBBH1-GlaA & bla URA3 ENO1 $1_{\mathrm{p}}-\mathrm{glaA}-\mathrm{ENO1} 1_{\mathrm{T}}$ & [19] \\
\hline yBBH1-AteA & bla URA3 ENO1 & {$[20]$} \\
\hline yBBH1-ApuA & bla URA3 ENO1 1 -apUA-ENO1 & [20] \\
\hline yBBH1-TemAc & bla URA3 ENO1 $1_{\mathrm{p}}$-temA-ENO1 & {$[20]$} \\
\hline yBBH1-TemA_Opt ${ }^{c}$ & bla URA3 ENO1 $1_{\mathrm{p}}$-temA_Opt-ENO1 & [20] \\
\hline yBBH1-TemG_Opt ${ }^{d}$ & bla URA3 ENO1 $1_{\mathrm{p}}$-temG_Opt-ENO1 $\mathrm{T}$ & {$[20]$} \\
\hline yBBH1-TemG_Opt-TemA & $\begin{array}{l}\text { bla URA3 ENO1 } 1_{\mathrm{p}} \text {-temG_Opt-ENO1 } \\
\text { ENO1; }\end{array}$ & This study \\
\hline pUG-amdSYMe & bla TEF1 $1_{\mathrm{p}}$-amdS-TEF1 ${ }_{\mathrm{T}}$ & [17] \\
\hline yBBH1-amdSYM & bla URA3 TEF1 $1_{\mathrm{P}}$-amdS-TEF1 $1_{\mathrm{T}}$ & This study \\
\hline
\end{tabular}

${ }^{a}$ Ethanol Red $^{\mathrm{TM}}$ Version 1, referred to as ER

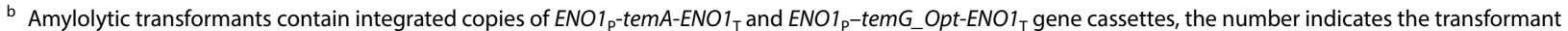
number during the screening process

c Accession no. XM_013469492 for the native Talaromyces emersonii a-amylase (temA-1866 bp/622 amino acids)

d Accession no. AJ304803 for the native T. emersonii glucoamylase (temG-1854 bp/618 amino acids)

e Assession no. P30669 for pUG-amdSYM plasmid

[19], which presented as benchmark yeast for this screening process (Fig. 1a, b).

After $120 \mathrm{~h}$, the Y294[TemG_Opt-TemA] strain had produced $51.71 \mathrm{~g} \mathrm{l}^{-1}$ ethanol, which represented a 1.6-fold improvement on the Y294[AmyA-GlaA] benchmark strain, producing $33.14 \mathrm{~g} \mathrm{l}^{-1}$ ethanol $(p=0.0013)$. Ethanol concentrations of 38.57 and $39.40 \mathrm{~g} \mathrm{l}^{-1}$ produced by the Y294[TemG_Opt-ApuA] 


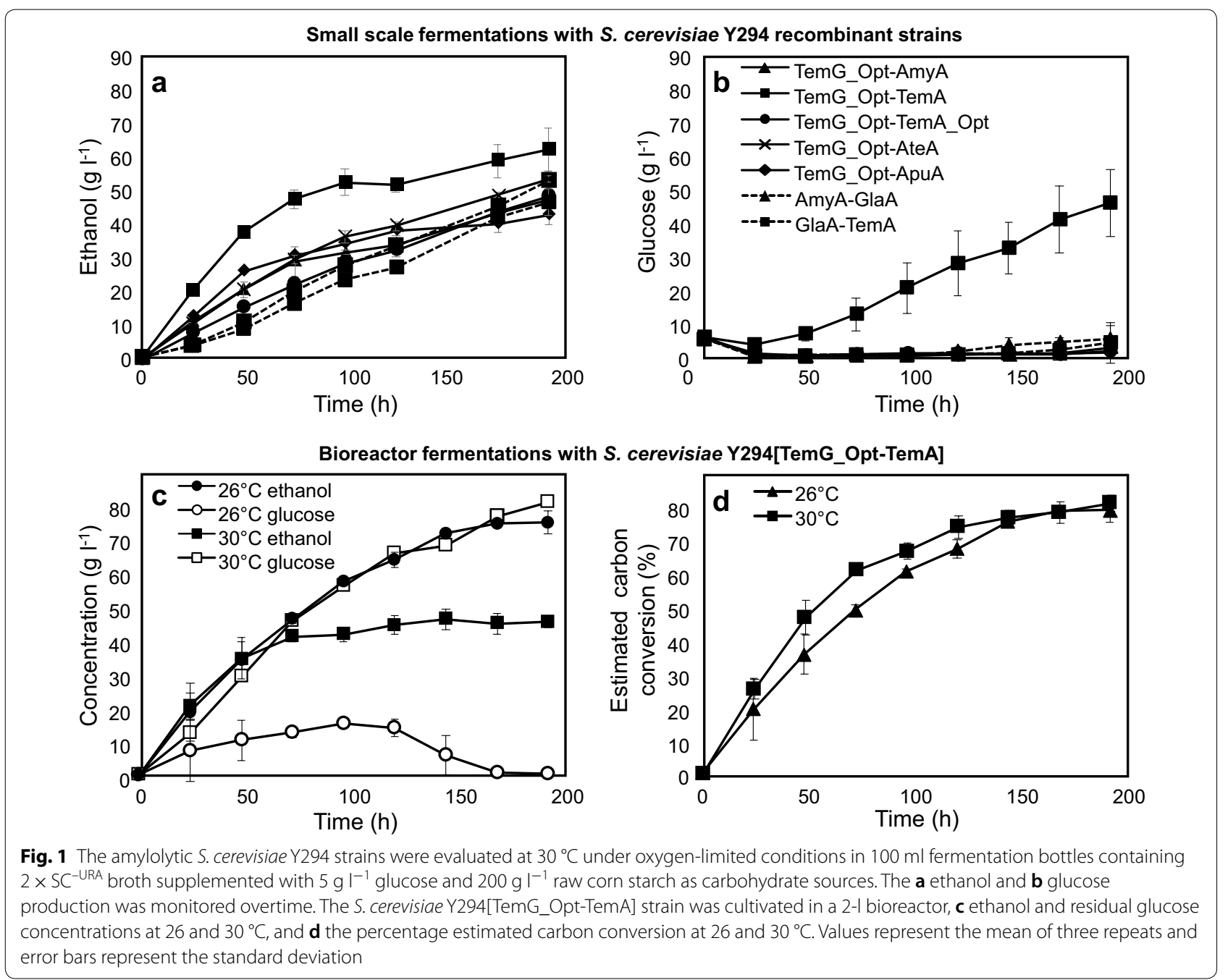

and Y294[TemG_Opt-AteA] strains (expressing the Aureobasidium pullulans apuA and Aspergillus terreus ate $A$-amylases), respectively, were also higher than the benchmark strain at $120 \mathrm{~h}$. At $192 \mathrm{~h}$, the superior Y294[TemG_Opt-TemA] strain expressing the native temA $\alpha$-amylase and codon-optimised temG_Opt glucoamylase (both genes originating from $T$. emersonii) accumulated the highest ethanol concentration $\left(62.20 \mathrm{~g} \mathrm{l}^{-1}\right)$, which was $60 \%$ of the theoretical ethanol yield (Fig. 1a, Table 2). However, the non-robust nature of the Y294 strain resulted in an incomplete fermentation and, as a consequence, the Y294[TemG_OptTemA] strain accumulated $46.30 \mathrm{~g} \mathrm{l}^{-1}$ residual glucose after $192 \mathrm{~h}$ of fermentation (Fig. $1 \mathrm{~b}$ and Table 2). Nevertheless, the unfermented glucose highlighted that the TemG_Opt-TemA enzyme combination efficiently hydrolysed raw corn starch and noticeably separated this strain's hydrolysing ability from the other recombinant strains, the latter resulted in insignificant residual glucose concentrations $\left(<6 \mathrm{~g} \mathrm{l}^{-1}\right)$ at the end of the fermentation (Fig. 1b).

There are a number of factors commonly associated with an incomplete fermentation, including the yeast strain's background and nitrogen availability [21]. Fermentation temperature control and rising ethanol concentrations may lead to fermentation arrest [22] and, therefore, fermentation temperature is considered as one of the main parameters with regards to ethanol production by SSF and CBP strategies. Moreover, the effect of high temperature is intensified by ethanol concentrations, which can significantly affect the yeast's fermenting capability [21]. When the cultivation temperature increases above the optimum growth temperature, the specific glucose uptake by $S$. cerevisiae is affected by changes to the physiology of the yeast cells and changes in the cell's membrane $[22,23]$ and this might explain the high glucose residual concentration 
Table 2 Product formation by the S. cerevisiae Y294 strains after $192 \mathrm{~h}$ of fermentation at $30{ }^{\circ} \mathrm{C}$ in $2 \times \mathrm{SC}^{-\mathrm{URA}}$ broth containing glucose $\left(5 \mathrm{~g} \mathrm{I}^{-1}\right)$ and raw corn starch $\left(200 \mathrm{~g} \mathrm{I}^{-1}\right)$, as carbon sources, as well as starch hydrolysing activities (U $\mathrm{ml}^{-1}$ ) when strains were grown in $2 \times \mathrm{SC}^{-U R A}$ broth for $72 \mathrm{~h}$

\begin{tabular}{|c|c|c|c|c|c|c|c|}
\hline S. cerevisiae Y294 strains & $\begin{array}{l}\text { [TemG_ } \\
\text { Opt- } \\
\text { AmyA] }\end{array}$ & $\begin{array}{l}\text { [TemG_ } \\
\text { Opt- } \\
\text { TemA] }\end{array}$ & $\begin{array}{l}\text { [TemG_Opt- } \\
\text { TemA_Opt] }\end{array}$ & [TemG_Opt-AteA] & $\begin{array}{l}\text { [TemG_- } \\
\text { Opt- } \\
\text { ApuA] }\end{array}$ & [GlaA-TemA] & [AmyA-GlaA] \\
\hline \multicolumn{8}{|l|}{ Substrate $\left(\mathrm{gl}^{-1}\right)$} \\
\hline Raw starch & 200 & 200 & 200 & 200 & 200 & 200 & 200 \\
\hline Glucose equivalent & 208.5 & 208.5 & 208.5 & 208.5 & 208.5 & 208.5 & 208.5 \\
\hline \multicolumn{8}{|l|}{ Products $\left(\left.g\right|^{-1}\right)$} \\
\hline Glucose & 2.72 & 46.30 & 1.67 & 1.94 & 1.21 & 4.12 & 5.30 \\
\hline Glycerol & 4.76 & 6.64 & 2.40 & 3.43 & 2.45 & 2.26 & 2.46 \\
\hline Maltose & 1.09 & 1.03 & 1.07 & 1.14 & 0.95 & 1.17 & 1.02 \\
\hline Acetic acid & 1.91 & 1.66 & 0.60 & 0.85 & 0.61 & 0.56 & 0.61 \\
\hline Ethanol & 47.40 & 62.20 & 48.71 & 53.46 & 43.12 & 46.56 & 52.78 \\
\hline $\mathrm{CO}_{2}^{\mathrm{a}}$ & 45.33 & 59.50 & 46.59 & 51.13 & 41.25 & 44.53 & 50.48 \\
\hline Total & 103.21 & 177.33 & 101.04 & 111.95 & 89.60 & 99.20 & 112.65 \\
\hline Estimated carbon conversion (\%) & 50 & 85 & 49 & 54 & 43 & 48 & 54 \\
\hline Ethanol yield ${ }^{b} \%$ of theoretical yield) & 46 & 60 & 47 & 51 & 41 & 45 & 51 \\
\hline Ethanol productivity ${ }^{c}$ & 0.25 & 0.32 & 0.25 & 0.28 & 0.23 & 0.24 & 0.28 \\
\hline \multicolumn{8}{|l|}{$2 \%$ raw starch assays $\left(\mathrm{U} \mathrm{ml}^{-1}\right)$} \\
\hline Total amylase activity ${ }^{d}$ & 0.21 & 0.47 & 0.16 & 0.21 & 0.30 & 0.13 & 0.09 \\
\hline Released glucose $\mathrm{e}^{\mathrm{e}}$ & 0.11 & 0.25 & 0.06 & 0.10 & 0.08 & 0.03 & 0.03 \\
\hline Released glucose equivalents ${ }^{f}$ & 0.16 & 0.43 & 0.19 & 0.35 & 0.32 & 0.05 & 0.05 \\
\hline \multicolumn{8}{|l|}{$0.2 \%$ soluble starch assays $\left(\mathrm{U} \mathrm{ml}^{-1}\right)$} \\
\hline Total amylase activity ${ }^{d}$ & 3.30 & 3.69 & 2.27 & 1.90 & 3.44 & 2.15 & 1.84 \\
\hline Released glucose $e^{e}$ & 0.69 & 1.00 & 0.16 & 0.32 & 0.13 & 0.01 & 0.02 \\
\hline
\end{tabular}

The assays were performed at $30^{\circ} \mathrm{C}$ in citrate buffer at $\mathrm{pH} 5$ with raw and soluble corn starch

a $\mathrm{CO}_{2}$ concentrations were deduced from the ethanol produced

b Ethanol yield (\% of the theoretical yield) was calculated as the amount of ethanol produced per gram of available glucose (at a specific time point)

c Ethanol productivity was calculated based on ethanol concentrations produced per $\mathrm{h}\left(\mathrm{g} \mathrm{I}^{-1} \mathrm{~h}^{-1}\right)$

d Reducing sugar assay detects all reducing sugars (monosaccharides and oligosaccharides)

e Glucose kit assay detects only glucose

${ }^{f}$ HPLC detection of glucose and maltose after raw starch assay, released glucose equivalents were converted to activity

observed in the Y294[TemG_Opt-TemA_Opt] fermentation broth (Fig. 1b).

The estimated carbon conversion of $85 \%$ displayed by the S. cerevisiae Y294[TemG_Opt-TemA] was 31\% higher than the Y294[TemG_Opt-AteA] strain, as well as the Y294[AmyA-GlaA] benchmark yeast (Table 2). The Y294[TemG_Opt-TemA] strain also showed an overall improvement in starch conversion to ethanol, compared to the previously constructed Y294[AteA-GlaA] strain [24], which produced $45.80 \mathrm{~g} \mathrm{l}^{-1}$ ethanol after $144 \mathrm{~h}$ with an estimated carbon conversion of $45 \%$.

The large difference in hydrolytic ability between recombinant strains could suggest that the specific TemG_Opt-TemA gene combination had enhanced synergistic activity for raw starch degradation, since even the Y294[TemG_Opt-TemA_Opt] strain, expressing the codon optimised T. emersonii $\alpha$-amylase displayed significantly lower estimated carbon conversion and decreased starch hydrolysing activities (Table 2). The best performing Y294[TemG_Opt-TemA] strain displayed a total amylase activity of $0.47 \mathrm{U} \mathrm{ml}^{-1}$ on raw starch at $30^{\circ} \mathrm{C}$, while the next highest activity was displayed by the Y294[TemG_Opt-ApuA] strain $\left(0.30 \mathrm{U} \mathrm{ml}^{-1}\right)$. The data for released glucose equivalents from raw starch supported the results for total amylase activity, as well as the high residual glucose concentrations $\left(46.30 \mathrm{~g} \mathrm{l}^{-1}\right)$ that were displayed by the Y294[TemG_Opt-TemA] strain under raw starch fermentation conditions (Table 2).

\section{S. cerevisiae Y294[TemG_Opt-TemA] bioreactor fermentations}

Although S. cerevisiae is known for its ethanol tolerance, most strains still lack the ability to continue fermenting glucose at temperatures that are higher than their 
normal cultivation temperature $\left(\sim 30-34{ }^{\circ} \mathrm{C}\right.$ for industrial strains, but lower for laboratory S. cerevisiae strains). The Y294[TemG_Opt-TemA] strain's fermenting capability was thus compared using a 2-1 benchtop bioreactor (1-l working volume) at both 26 and $30{ }^{\circ} \mathrm{C}$, respectively (Fig. 1c, d). The optimum growth temperature for the Y294 strain is lower than $30^{\circ} \mathrm{C}$, therefore, a fermentation incubation temperature of $26^{\circ} \mathrm{C}$ was included, as it more closely represents the ideal temperature for this laboratory $S$. cerevisiae strain's fermenting ability (reported as $25{ }^{\circ} \mathrm{C}$ for the ATCC $^{\circledR} 201160^{\mathrm{TM}}$; https://www.atcc.org/ / ps/201160.ashx). After $192 \mathrm{~h}$ at $26^{\circ} \mathrm{C}$, a 1.8-fold improvement in the ethanol concentration (compared to at $30^{\circ} \mathrm{C}$ ) was detected and there was no residual glucose in the fermentation broth (Fig. 1c). From 144 h, the resulting estimated carbon conversion was similar for both fermentation temperatures ( 80\%) (Fig. 1d), demonstrating that the lower temperature did not negatively affect the starch hydrolysis and prevented the accumulation of unfermented glucose.

After $192 \mathrm{~h}$ at $30{ }^{\circ} \mathrm{C}$, the estimated carbon conversion displayed by the S. cerevisiae Y294[TemG_Opt-TemA] strain was similar for the $100 \mathrm{ml}$ and 1-l bioreactor fermentations, 85 and $81 \%$, respectively (Table 2 and Fig. 1d). However, at $30{ }^{\circ} \mathrm{C}$, ethanol levels obtained by S. cerevisiae Y294[TemG_Opt-TemA] were found to be lower than those detected at a smaller scale (Fig. 1a). This finding could be due to an increase in stress exposure linked to limited transportation and elimination of $\mathrm{CO}_{2}$, toxic metabolites and additional heat generated by agitation [25]. The effect of temperature on fermentation products has been previously observed by a number of different research groups $[23,26]$ and it is suggested that in this study a lower incubation temperature lessened the physiological stress on the cells and enabled the S. cerevisiae Y294[TemG_Opt-TemA] laboratory strain to ferment all the available glucose to ethanol. An additional factor that may have intensified the effect of fermentation temperature, is the effect of metabolic heat. Although the fermentations were performed in incubators set at 26 and $30{ }^{\circ} \mathrm{C}$, respectively, the internal temperature of the broth was measured to be $\sim 1$ to 2 degrees higher; this could be due to the heat released by the metabolic activity of the yeast [27] and may have a negative impact on the yeast cells' vitality and/or viability.

\section{Industrial strain construction and screening}

The construction of a robust, temperature tolerant CBP yeast that can simultaneously express heterologous amylases and produce ethanol efficiently would yield more cost-effective ethanol production from starchy feedstocks. The demand for higher temperature fermentations began in the 1980s [28], with benefits including an easier ethanol extraction process more suited to fuel ethanol production, decreased operational costs (especially in regions with hot climates where cooling of fermentation vessels is required), improved hydrolysis conditions and reduced risk of contamination [29]. Currently, the fermentation temperature used in industry ranges between 30 and $34{ }^{\circ} \mathrm{C}$ [30] and it is desirable to select an appropriate industrial strain for CBP that is able to continue fermenting sugars above the recommended fermentation temperature.

The S. cerevisiae Ethanol $\operatorname{Red}^{\mathrm{TM}}$ strain (Fermentis, a division of S. I. Lesaffre, Lille, http://www.fermentis. com) was chosen as the main industrial expression host for this study (henceforth referred to as the ER strain), since it is predominantly applied in first-generation bioethanol production from corn and wheat $[13,31]$. It is characterised by excellent fermentation capacity and yield, high robustness, stress- and thermo-tolerance [15]. For comparative purposes, the S. cerevisiae M2n South African distillery yeast strain was included as a parental strain [16]. The best performing amylase combination (T. emersonii's temA and temG_Opt genes), identified through the fermentation screening process on raw corn starch (Fig. 1a), was selected for industrial strain transformation. The linear $E N O 1_{\mathrm{P}}-t e m A-E N O 1_{\mathrm{T}}$ and $E N O 1_{\mathrm{P}}-$ temG_Opt-ENO1 $1_{\mathrm{T}}$ DNA gene cassettes (Fig. 2a), flanked by the delta- $(\delta)$ sequences, were amplified by PCR using the primers listed in Table 3; $\delta$-sequences are the long terminal repeats (LTRs) of the Ty1 and 2 retrotransposons and were targeted in the ER and M2n industrial strains' genomes to generate multi-copy integrations [32, 33]. A markerless transformation method was also employed; the amdS selection marker gene (encoding for acetamidase) present on an episomal vector (Fig. 2b) was co-transformed with the gene cassettes (Fig. 2a), followed by plasmid curing (marker recycling).

The industrial $S$. cerevisiae transformants were screened on SC-Ac plates containing 2\% soluble starch (Fig. 2c) and only transformants that produced zones of hydrolysis were selected for further testing. PCR was used to confirm the integration of the respective

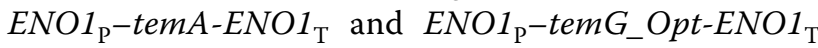
gene cassettes in transformants that produced prominent clearing zones (representing starch hydrolysis). From the 20 transformants selected for each strain, only S. cerevisiae strains ER T1, ER T12, M2n T1 and M2n $\mathrm{T} 2$ contained both integrated gene cassettes. These four strains were evaluated using liquid assays at both 30 and $37{ }^{\circ} \mathrm{C}$ to quantify the extracellular amylase activity on soluble and raw corn starch (Table 4). The higher the incubation temperature, the greater the extent of starch hydrolysis; at $37^{\circ} \mathrm{C}$, the $S$. cerevisiae ER T12 strain displayed the highest total amylase activity, $15.30 \mathrm{U} \mathrm{ml}^{-1}$ 
a

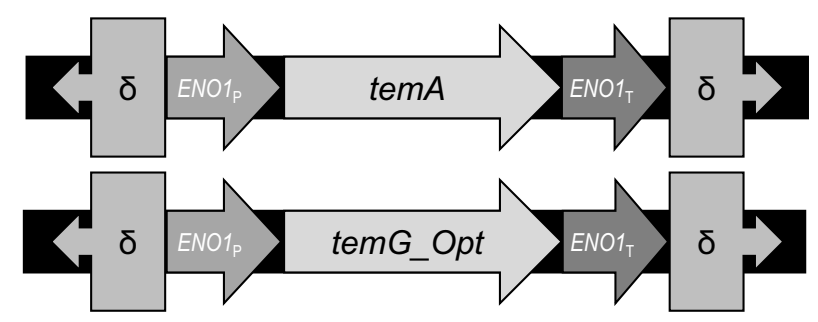

b

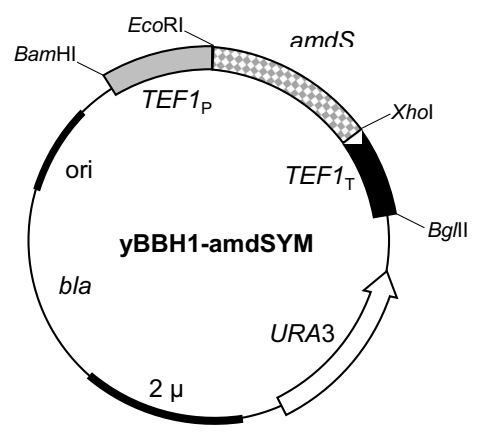

C

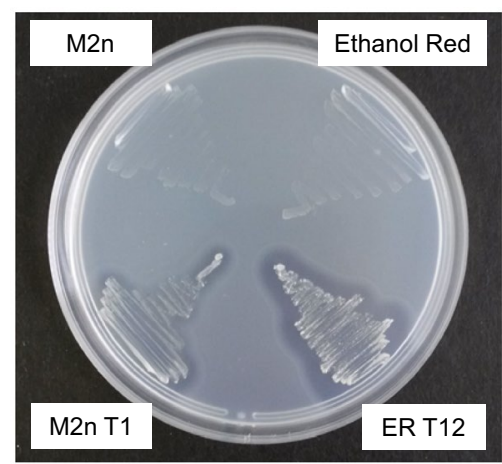

d

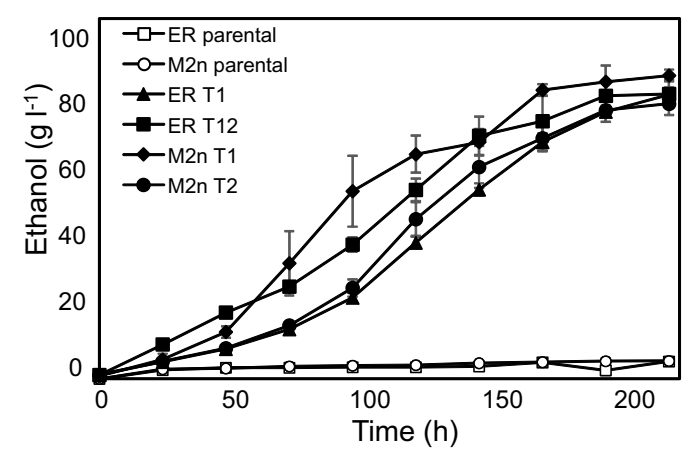

Fig. 2 Construction of amylolytic S. cerevisiae M2n and ER industrial strains. The ENO1 temA and temG_Opt gene cassettes (a) were amplified using PCR and contained flanking regions homologous to the $\delta$-integration sites. The $T E F 1_{\mathrm{p}}-a m d S-T E F 1_{T}$ cassette was cloned onto yBBH1 (b) to generate the $\mathrm{yBBH} 1$-amdSYM yeast expression vector. Soluble starch plate assays to visualise hydrolysis zones surrounding the recombinant strains (c), following incubation on soluble starch at $30^{\circ} \mathrm{C}$. The S. cerevisiae M2n and ER parental strains displayed no extracellular amylase activity. Ethanol concentrations produced by $S$. cerevisiae recombinant strains during fermentation in YPD with $5 \mathrm{~g} \mathrm{I}^{-1}$ glucose and with $200 \mathrm{~g} \mathrm{I}^{-1} \mathrm{corn}$ starch at $30^{\circ} \mathrm{C}$ (d) were compared to the parental strains. Data are the mean of three repeats showing standard deviation

Table 3 PCR primers designed and used in this study with the relevant restriction sites underlined (Xhol=ctcgag, BamHI = ggatcc, BgllI = agatct)

\begin{tabular}{|c|c|}
\hline Primer name & Sequence $\left(5^{\prime}-3^{\prime}\right)$ \\
\hline ENOCASS-L & gtgcggtatttcacaccgcataggagatcgatcccaattaatgtgagttacctcactc \\
\hline ENOCASS-R & cgggcctcttcgctattacgccagagcttagatct \\
\hline amdSYMCas-L & ccgcgcgttggecgattcattaatccaggatccacatggaggcccagaataccctccttgac \\
\hline amdSYMCas-R & gggcctcttcgctattacgccagagcttagatctcagtatagcgaccagcattcacatacttaa \\
\hline Delta-ENO1_Promoter-L & $\begin{array}{l}\text { tggaataaaaatccactatcgtctatcaactaatagttatattatcaatatattatcatatacggt- } \\
\text { gttaagatgatgacataagttatgagaagctgtcggatcccaattaatgtgagttacctcac }\end{array}$ \\
\hline Delta-ENO1_Terminator-R & $\begin{array}{l}\text { tgagatatatgtgggtaattagataattgttgggattccattgttgataaaggctataatattag- } \\
\text { gtatacagaatatactagaagttctcctcgaggatagatctcctatgcggtgtgaaatac- } \\
\text { cgc }\end{array}$ \\
\hline
\end{tabular}

after $72 \mathrm{~h}$, which was 3.8 -fold higher than the $S$. cerevisiae M2n T1 strain's activity of $3.99 \mathrm{U} \mathrm{ml}^{-1}$ (reducing sugar assay on soluble starch). The results from the raw starch assay performed at $37{ }^{\circ} \mathrm{C}$ also indicated that the $S$. cerevisiae ER T12 strain performed the best, displaying a total amylase activity of $1.38 \mathrm{U} \mathrm{ml}^{-1}$, which was significantly higher than the $S$. cerevisiae M2n T1 strain's activity of $0.48 \mathrm{U} \mathrm{ml}^{-1}$, after $72 \mathrm{~h}$. Mitotic stability was also tested and after 250 generations both ER T12 and M2n T1 strains were confirmed to be mitotically stable; these strains displayed hydrolytic ability on soluble corn starch. 
Table 4 Soluble starch hydrolysing activities (U $\mathrm{ml}^{-1}$ ) of the industrial S. cerevisiae ER and M2n transformants expressing the temG_Opt glucoamylase and temA a-amylase originating from $T$. emersonii when grown in $2 \times$ SC $^{-U R A}$ broth for $72 \mathrm{~h}$

\begin{tabular}{lllll}
\hline \multicolumn{2}{l}{$\%$ raw starch } & & \multicolumn{2}{l}{$0.2 \%$ soluble starch } \\
\cline { 5 - 6 } & $30^{\circ} \mathrm{C}$ & & $37^{\circ} \mathrm{C}$ & $37^{\circ} \mathrm{C}$
\end{tabular}

Total amylase activity (Reducing sugar assay ${ }^{\mathrm{a}}$ )

$\begin{array}{ccccr}\text { ERT1 } & 0.29(0.10) & 0.42(0.09) & 2.03(0.35) & 3.39(0.20) \\ \text { ERT12 } & 0.99(0.02) & 1.38(0.08) & 9.11(0.05) & 15.30(0.52) \\ \text { M2nT1 } & 0.33(0.03) & 0.48(0.02) & 2.21(0.05) & 3.99(0.28) \\ \text { M2nT2 } & 0.20(0.02) & 0.29(0.03) & 1.28(0.30) & 2.46(0.15) \\ \text { Released glucose (Glucose kit assay }) & & \\ \text { ERT1 } & 0.15(0.03) & 0.16(0.04) & 1.47(0.23) & 2.12(0.18) \\ \text { ERT12 } & 0.44(0.04) & 0.48(0.06) & 4.43(0.29) & 6.32(0.22) \\ \text { M2nT1 } & 0.27(0.01) & 0.29(0.02) & 1.11(0.10) & 1.59(0.12) \\ \text { M2nT2 } & 0.16(0.01) & 0.17(0.01) & 0.65(0.15) & 0.96(0.13)\end{array}$

The assays were performed at $30^{\circ} \mathrm{C}$ and $37^{\circ} \mathrm{C}$ in citrate buffer at $\mathrm{pH} 5$ with raw and soluble corn starch. Parental strains did not give any starch-degrading activities. Values represent the mean of three repeats and standard deviations are reported in parentheses

${ }^{a}$ Reducing sugar assay detects all reducing sugars (monosaccharides and oligosaccharides)

${ }^{b}$ Glucose assay detects only glucose

These four industrial transformants were subsequently evaluated under fermentative conditions on raw corn starch (Fig. 2d). Significant differences in ethanol concentrations were noted during the first $96 \mathrm{~h}$ of fermentation at $30{ }^{\circ} \mathrm{C}$ (Fig. 2d). These differences followed similar trends to those observed during the liquid assays, with the $S$. cerevisiae ER T12 strain producing ethanol the quickest during the first $48 \mathrm{~h}$. However, after $192 \mathrm{~h}$, ethanol concentrations plateaued around $\sim 80-90 \mathrm{~g} \mathrm{l}^{-1}$. Both the assay and preliminary fermentation results showed that S. cerevisiae ER T12 and M2n T1 hydrolysed starch and fermented the sugars quicker than the $S$. cerevisiae ER T1 and M2n T2 strains (Table 4 and Fig. 2d) and were therefore selected for further evaluation.

\section{Next generation sequencing data analysis of $S$. cerevisiae ER T12 and M2n T1 genomes}

Numerous studies have employed $\delta$-elements for gene insertions because of their abundancy-several hundred $\delta$-elements dispersed in the $S$. cerevisiae chromosomes [32]. These sites were chosen for the integration of the temA and temG_Opt genes because they created an opportunity to generate transformants with a varying number of gene copies, as well as different ratios of the amylolytic genes. Gene integration into targeted DNA sequences on the yeast's chromosomes using the $\delta$-sequences of the Ty retrotransposon allows for multiple gene integration and
Table 5 Average coverage of integrated temA and temG Opt genes, as well as housekeeping genes into $S$. cerevisiae ER T12 and M2n T1 genomes

\begin{tabular}{lll}
\hline Genes & ER T12 & M2n T1 \\
\hline temA & $152(4.46)$ & $39(0.92)$ \\
temG_Opt & $245(7.20)$ & $41(0.99)$ \\
ALG9 & 34 & 43 \\
TFC1 & 34 & 42 \\
PGK1 & 34 & 38 \\
ACT1 & 35 & 44 \\
Average housekeeping genes & 34 & 42 \\
\hline
\end{tabular}

Italic fonts report copy numbers integrated into each genome estimated considering the ratio between the average coverage of the integrated genes and the average coverage of the four housekeeping genes

has assisted high expression levels in S. cerevisiae [16]. However, the $\delta$-sites generate transformants with different expression efficiencies as the positions of the integrated cassettes are unknown and their numbers could vary substantially between transformants [34]. While Cho et al. [35] reported high copy numbers (maximum of 44 copies), most articles report less than 10 copies.

To identify the number of integrated amylase gene copies, the genomes of the S. cerevisiae ER T12 and M2n T1 amylase-producing strains were sequenced. The average number of paired-end reads $(2 \times 150 \mathrm{bp})$ for the strains was $3,750,382$, resulting in a 106- and 169-fold genome coverage for S. cerevisiae M2n T1 and ER T12, respectively. The de novo assembly generated a draft genome of 11.7 and $11.6 \mathrm{Mb}$ for S. cerevisiae M2n T1 and ER T12 strains, respectively. High-quality assemblies were composed by 251 and 159 scaffolds, with a $\mathrm{N}_{50}$ of 99334 and 188573 for S. cerevisiae M2n T1 and ER T12, respectively. Copy numbers for integrated genes in each genome were determined considering the ratio between the average coverage of selected housekeeping genes for S. cerevisiae and the average coverage of the integrated genes (Table 5).

Saccharomyces cerevisiae M2n T1 contains a single copy of each of the temA and temG_Opt genes, whilst the ER T12 strain has an estimated 4 temA and 7 temG_Opt copies. This finding is consistent with the higher enzymatic activities on soluble starch after $72 \mathrm{~h}$ at $37^{\circ}$ by S. cerevisiae ER T12, which produced up to 3.8 and 3.9-fold the total amylase activity and released glucose, respectively, compared to S. cerevisiae M2n T1 (Table 4).

Fermentations with the industrial S. cerevisiae strains and GSHE cocktail

CBP offers numerous advantages, however, at the start of a fermentation process the recombinant proteins still need to be produced by the yeast strain before substrate 
hydrolysis can accelerate. Therefore, enzyme supplementation was tested to enhance the rate of substrate hydrolysis to glucose during the first $24 \mathrm{~h}$. The amylolytic S. cerevisiae ER T12 and M2n T1 strains were also compared to a simulated SSF control with the parental industrial strains so that a comparison to a raw starch CBP process could be made. The GSHE cocktail (used for enzyme supplementation) is a commercial rawstarch degrading preparation from DuPont Industrial Biosciences and the recommended GSHE dosage (100\%) was calculated as $1.42 \mu \mathrm{l} \mathrm{g}^{-1}$ starch, according to the manufacturer's specifications [36, 37]. The parental $S$. cerevisiae industrial strains supplemented with $28.3 \mu \mathrm{l}$
GSHE per $100 \mathrm{ml}$ fermentation (100\% dosage of GSHE) represented the control experiment for each strain and a substrate loading of $200 \mathrm{~g} \mathrm{l}^{-1}$ raw corn starch was used for all the fermentations (Fig. 3). At $30{ }^{\circ} \mathrm{C}$, three different enzyme dosages in combination with the CBP strains were evaluated based on the percentage of the recommended enzyme loading: $2.8 \mu \mathrm{l}(10 \%), 5.7 \mu \mathrm{l}(20 \%)$ and $14.2 \mu \mathrm{l}\left(50 \%\right.$-only for ER T12), while at $37{ }^{\circ} \mathrm{C}$ a $2.8 \mu \mathrm{l}$ (10\%) dosage of GSHE was evaluated with both $\mathrm{S}$. cerevisiae ER T12 and M2n T1 strains.

At $30{ }^{\circ} \mathrm{C}$, the ethanol profiles for the industrial S. cerevisiae parental strains were similar for the respective enzyme supplementation condition (Fig. $3 \mathrm{a}$ and b). By

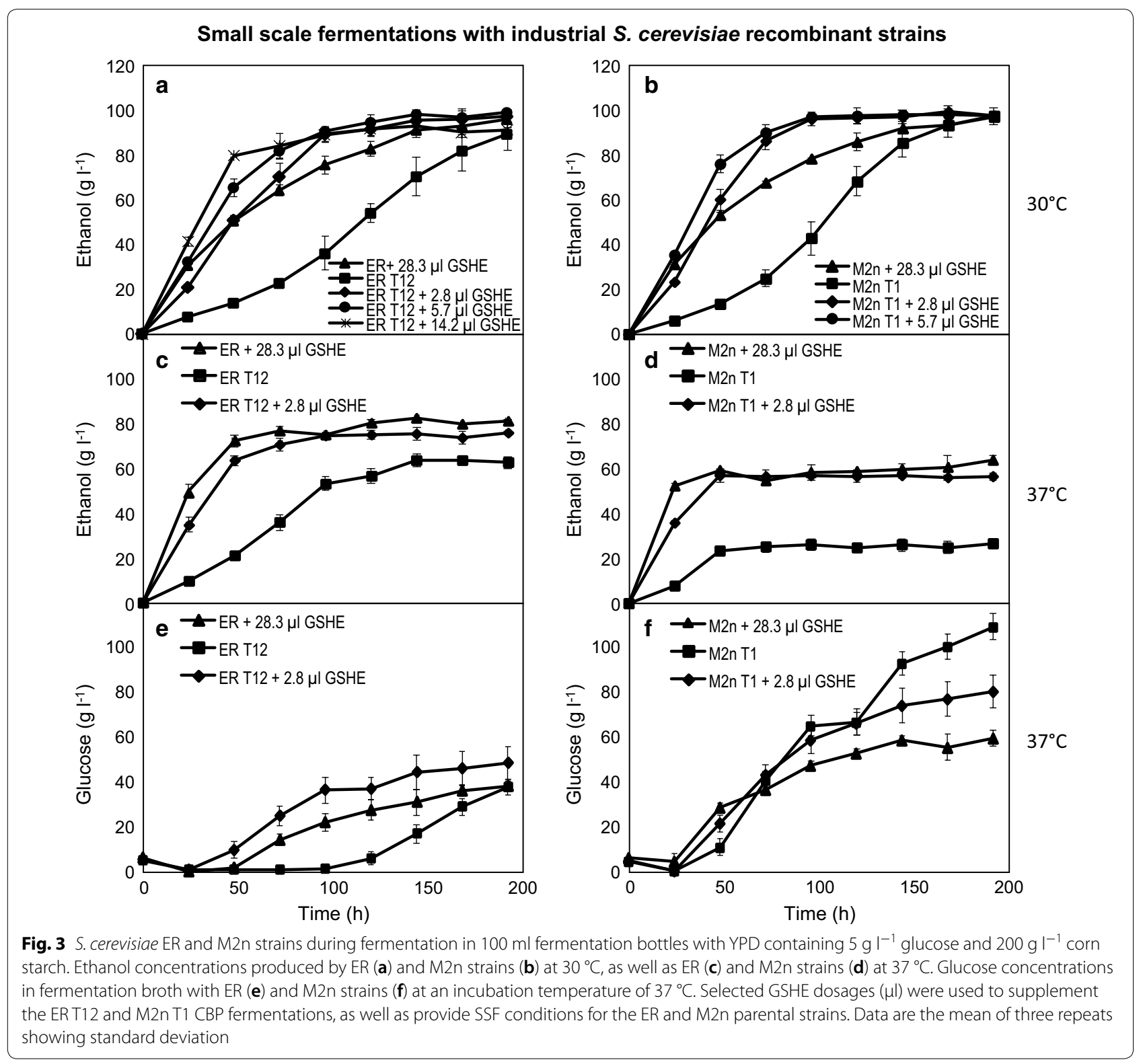


$48 \mathrm{~h}$, the S. cerevisiae ER T12 strain supplemented with $2.8 \mu \mathrm{l}$ GSHE (10\% of the recommended dosage) had produced $50.78 \mathrm{~g} \mathrm{l}^{-1}$ ethanol and also displayed an estimated carbon conversion of $50 \%$ (data not shown), compared to that of the control SSF process with the S. cerevisiae parental strain supplemented with $28.3 \mu \mathrm{l}$ GSHE, which produced $50.57 \mathrm{~g} \mathrm{l}^{-1}$ ethanol (Fig. 3a). Similarly, the $S$. cerevisiae M2n T1 strain supplemented with $2.8 \mu \mathrm{l} \mathrm{GSHE}$ produced $58.87 \mathrm{~g} \mathrm{l}^{-1}$ ethanol, compared to the S. cerevisiae parental strain with $28.3 \mu \mathrm{l}$ GSHE which produced $53.54 \mathrm{~g} \mathrm{l}^{-1}$ ethanol, after $48 \mathrm{~h}$ (Fig. 3b). Therefore, for both strain backgrounds, the CBP supplemented conditions produced similar ethanol concentrations compared to the SFF control at $48 \mathrm{~h}$, thereafter the CBP supplemented conditions displayed a higher rate of ethanol production.

After $96 \mathrm{~h}$, the ethanol produced by the S. cerevisiae ER T12 strain supplemented with $2.8 \mu \mathrm{l} \mathrm{GSHE}\left(89.20 \mathrm{~g} \mathrm{l}^{-1}\right)$ was similar to the amount of ethanol produced by the $S$. cerevisiae ER T12 strain supplemented with $5.7 \mu \mathrm{l} \mathrm{GSHE}$ (90.82 $\mathrm{g} \mathrm{l}^{-1}$ ) (Fig. 3a) and the estimated carbon conversion displayed was between 87 and $89 \%$ (data not shown). Under these two conditions, a significant increase in ethanol concentration was observed at $96 \mathrm{~h}$, compared to the industrial S. cerevisiae control experiment (supplemented with a $100 \%$ GSHE loading), which produced $75.47 \mathrm{~g} \mathrm{l}^{-1}$ ethanol and displayed an estimated carbon conversion of $74 \%$. Therefore, the addition of $2.8 \mu \mathrm{l}$
GSHE (10\% of the recommended dosage) was sufficient to obtain results that were comparable to an SSF control. If the aim is to decrease the fermentation time, higher dosages of GSHE can be used in combination with the $S$. cerevisiae ER T12 strain. For instance, supplementing the CBP fermentation with $50 \%$ of the recommended dosage (14.2 $\mu \mathrm{l}$ GSHE) did not improve the final ethanol concentrations, but did result in a decreased fermentation time, with the maximum ethanol concentration being reached at $96 \mathrm{~h}$, instead of $192 \mathrm{~h}$. A higher enzyme loading thus contributed to increased ethanol productivity during the initial stage of fermentation at $30^{\circ} \mathrm{C}$, but the maximum ethanol concentrations achieved for the CBP supplemented experiments were similar $\sim 95-97 \mathrm{~g} \mathrm{l}^{-1}$ (Fig. 3a, b; Table 6).

During fermentation with the CBP industrial strains there was an initial "lag" phase in estimated carbon conversion up until $48 \mathrm{~h}$. This was expected since the strains first had to adjust to the fermentation conditions and produce amylases de novo. However, the amylolytic CBP yeasts described in this study were able to continually replenish the recombinant enzymes in the fermentation broth and together with GSHE supplementation facilitated an overall increase in estimated carbon conversion (Table 6). On the other hand, GSHE are in abundance at the start of an industrial SSF cold hydrolysis set-up and rapidly produced glucose upon addition. However, the enzyme's efficiency may decrease overtime due to their

Table 6 Product formation by S. cerevisiae ER and M2n strains after $192 \mathrm{~h}$ of fermentation at $30^{\circ} \mathrm{C}$ and $37^{\circ} \mathrm{C}$ in YPD media (containing $5 \mathrm{~g} \mathrm{I}^{-1}$ glucose) and raw corn starch $\left(200 \mathrm{~g} \mathrm{I}^{-1}\right)$, supplemented with selected GSHE dosages

\begin{tabular}{|c|c|c|c|c|c|c|c|c|c|c|c|c|}
\hline \multirow[b]{2}{*}{ S. cerevisiae strains } & \multicolumn{6}{|l|}{$30^{\circ} \mathrm{C}$} & \multicolumn{6}{|l|}{$37^{\circ} \mathrm{C}$} \\
\hline & $\mathrm{ER}^{\mathrm{a}}$ & $M 2 n^{a}$ & ERT12 & M2n T1 & ERT12 & $\mathrm{M} 2 \mathrm{n} \mathrm{T1}$ & $\mathrm{ER}^{\mathrm{a}}$ & $M 2 n^{a}$ & ERT12 & M2n T1 & ERT12 & M2n T1 \\
\hline GSHE added $(\mu \mathrm{l})$ & 28.3 & 28.3 & 2.8 & 2.8 & 0 & 0 & 28.3 & 28.3 & 2.8 & 2.8 & 0 & 0 \\
\hline \multicolumn{13}{|l|}{ Substrate $\left(\mathrm{g} \mathrm{I}^{-1}\right)$} \\
\hline Raw starch & 200 & 200 & 200 & 200 & 200 & 200 & 200 & 200 & 200 & 200 & 200 & 200 \\
\hline Glucose equivalent & 208.5 & 208.5 & 208.5 & 208.5 & 208.5 & 208.5 & 208.5 & 208.5 & 208.5 & 208.5 & 208.5 & 208.5 \\
\hline \multicolumn{13}{|l|}{ Products $\left(\mathrm{g} \mathrm{l}^{-1}\right)$} \\
\hline Glucose & 0.02 & 0.31 & 0.02 & 3.28 & 0.22 & 0.09 & 40.12 & 62.30 & 50.79 & 83.92 & 39.62 & 113.91 \\
\hline Glycerol & 4.07 & 4.30 & 4.76 & 4.59 & 3.18 & 3.73 & 5.72 & 5.64 & 6.07 & 5.54 & 5.50 & 2.63 \\
\hline Acetic acid & 0.00 & 0.00 & 0.90 & 0.31 & 0.64 & 0.00 & 0.83 & 0.66 & 0.95 & 0.39 & 1.28 & 0.95 \\
\hline Ethanol & 95.90 & 97.34 & 97.16 & 97.84 & 89.35 & 98.13 & 81.30 & 63.99 & 75.99 & 56.82 & 62.64 & 26.96 \\
\hline Maltose & 0.79 & 0.71 & 0.31 & 0.37 & 1.95 & 0.96 & 1.27 & 2.53 & 2.14 & 3.23 & 0.70 & 3.37 \\
\hline $\mathrm{CO}_{2}$ & 91.73 & 93.11 & 92.93 & 93.59 & 85.46 & 93.87 & 77.76 & 61.21 & 72.69 & 54.35 & 59.92 & 25.79 \\
\hline Total & 192.51 & 195.77 & 196.07 & 199.98 & 180.79 & 196.78 & 207.00 & 196.33 & 208.63 & 204.25 & 169.66 & 173.62 \\
\hline Estimated carbon conversion (\%) & 92 & 94 & 94 & 96 & 87 & 94 & 99 & 94 & 100 & 98 & 81 & 83 \\
\hline Ethanol yield ${ }^{b}$ (\% of theoretical yield) & 92 & 93 & 93 & 94 & 86 & 94 & 78 & 61 & 73 & 55 & 60 & 26 \\
\hline Ethanol productivity ${ }^{c}$ & 0.50 & 0.51 & 0.51 & 0.51 & 0.47 & 0.51 & 0.42 & 0.33 & 0.40 & 0.30 & 0.33 & 0.14 \\
\hline
\end{tabular}

\footnotetext{
a Parental strains under SSF conditions

${ }^{b}$ Ethanol yield (\% of the theoretical yield) was calculated as the amount of ethanol produced per gram of available glucose (at a specific time point)

${ }^{c}$ Ethanol productivity was calculated based on ethanol concentrations produced per hour $\left(\mathrm{g} \mathrm{I}^{-1} \mathrm{~h}^{-1}\right)$
} 
half-life. Results from this study clearly highlight the benefit of adding GSHE in combination with the amylolytic yeast strains, and limited enzyme supplementation provided the necessary boost to increase the rate of fermentation with the CBP yeast strains.

\section{Effect of fermentation temperature}

At $30{ }^{\circ} \mathrm{C}$, the final ethanol concentrations differed significantly between the S. cerevisiae M2n T1 and ER T12 strains under CBP conditions. The S. cerevisiae M2n T1 achieved a maximum ethanol concentration of $98.13 \mathrm{gl}^{-1}$ after $192 \mathrm{~h}$, which was significantly higher $(p=0.0054)$ $\left(8.78 \mathrm{~g} \mathrm{l}^{-1}\right)$ than the $S$. cerevisiae ER T12 strain's ethanol concentration of $89.35 \mathrm{~g} \mathrm{l}^{-1}$ (Fig. 3a, b). However, at an incubation temperature of $37^{\circ} \mathrm{C}$, it was clear that the $S$. cerevisiae ER T12 strain had a greater fermentation vigour and was more tolerant to increasing ethanol concentrations, compared to the $S$. cerevisiae M2n T1 strain (Fig. 3c, d). Under CBP conditions (without enzyme supplementation), the $S$. cerevisiae ER T12 strain had a higher temperature tolerance and was able to ferment for longer at $37^{\circ} \mathrm{C}$ (compared to the M2n T1 strain) and produced a $>$ twofold increase in ethanol concentration after 192 h (Fig. 3c, d). Although the recombinant S. cerevisiae M2n T1 strain produced a higher ethanol yield at $30{ }^{\circ} \mathrm{C}$, it was severely affected at an incubation temperature of $37^{\circ} \mathrm{C}$, where it reached an incomplete fermentation after $48 \mathrm{~h}$ (Fig. 3d). On average, glycerol concentrations were also higher at $37^{\circ} \mathrm{C}$ (Table 6), signifying enhanced stress on both strains [14].

The extent of estimated carbon conversion displayed by the S. cerevisiae ER T12 strain (no GSHE supplementation) was similar $(\sim 81-87 \%)$ at the two fermentation temperatures (Table 6), while the estimated carbon conversion displayed by the $S$. cerevisiae M2n T1 strain was $11 \%$ higher at $30{ }^{\circ} \mathrm{C}$, compared to the estimated carbon conversion at $37^{\circ} \mathrm{C}$ (Table 6). Both the amylolytic S. cerevisiae ER T12 and M2n T1 strains had lower ethanol productivity at $37^{\circ} \mathrm{C}$, compared to at $30^{\circ} \mathrm{C}$ and residual glucose levels were $>40 \mathrm{~g} \mathrm{l}^{-1}$ at $37^{\circ} \mathrm{C}$ (Fig. 3e, f, Table 6), which represented a large amount of unfermented glucose, especially for the S. cerevisiae M2n strains. Overall, results showed that thermotolerance played a major role in the fermentation vigour of industrial S. cerevisiae ER T12 and M2n T1 strains and affected the conversion of glucose to ethanol, thus supporting the observation in Fig. 1c with the Y294[TemG_Opt-TemA] strain.

\section{CBP industrial strains}

There are currently no industrial amylolytic S. cerevisiae strains (co-expressing an $\alpha$-amylase and glucoamylase gene) available for the conversion of starch to ethanol under CBP conditions [38] and few studies have successfully engineered S. cerevisiae ER for the expression of gene cassettes or adapted it for desired characteristics. Demeke et al. [15] developed a D-xylose fermenting strain, Wallace-Salinas and Gorwa-Grauslund [39] developed a strain capable of fermenting spruce hydrolysate and Stovicek et al. [40] introduced a xylose consumption pathway. To our knowledge, this study represents the first to engineer S. cerevisiae ER for the coexpression of both an $\alpha$-amylase and glucoamylase gene for efficient raw corn starch conversion. It also represents the first study to investigate the effects of GSHE supplementation in combination with industrial amylolytic CBP yeast strains.

Compared to other studies, the industrial strains constructed in this study performed well on raw corn starch. Final ethanol concentrations were higher than those reported for the amylolytic haploid yeast strain, which produced $46.5 \mathrm{~g} \mathrm{l}^{-1}$ of ethanol from $200 \mathrm{~g} \mathrm{l}^{-1}$ of raw corn starch after $120 \mathrm{~h}$ of fermentation [41]. The novel amylolytic yeast strains presented here were superior in their ethanol production, producing 54.06 and $68.52 \mathrm{~g} \mathrm{l}^{-1}$ ethanol for the S. cerevisiae ER T12 and M2n T1 strains, respectively, after $120 \mathrm{~h}$ (Fig. 3a, b), even with a much lower inoculum size $\left(10 \% \mathrm{v} \mathrm{v}^{-1}\right.$ was used in this study). Furthermore, since the recombinant amylases were secreted into the fermentation broth they can have increased physical contact with the starch granules, compared to other recombinant yeast that may display amylases on the cell's surface [41]. Results also showed significant improvements when compared to the industrial S. cerevisiae M2n[TLG1-SFA1] and MEL2[TLG1SFA1] amylolytic strains [16] that produced $64 \mathrm{~g} \mathrm{l}^{-1}$ ethanol from $200 \mathrm{~g} \mathrm{l}^{-1}$ raw corn starch (at a bioreactor scale), corresponding to $55 \%$ of the theoretical ethanol yield, as well as the $S$. cerevisiae Mnua1[AmyA-GlaA] strain [19] that produced $65.83 \mathrm{~g} \mathrm{l}^{-1}$ ethanol (after 10 days) representing $57 \%$ of the theoretical ethanol yield. Ethanol yields (\% of the theoretical) obtained from the recombinant industrial strains in this study were $>85 \%$ $\left(30{ }^{\circ} \mathrm{C}\right.$ incubation temperature, Table 6) and thus represented a significant improvement on previously constructed CBP strains.

The cost of commercial enzyme addition has been estimated at 4.8 US cents per gallon, representing $8.3 \%$ of the total possessing costs in ethanol production from corn [42]. The amylolytic S. cerevisiae ER T12 and M2n $\mathrm{T} 1$ strains represent a novel alternative for lowering the enzyme dosage for raw starch hydrolysis, as well as being able to provide constant amylolytic activity for a continuous cold fermentation process. Furthermore, the use of amylolytic CBP yeast would allow for a simplified fermentation design, since pretreatment steps and costs can be bypassed [9]. 


\section{Conclusion}

An improvement in the estimated carbon conversion of raw corn starch was achieved in this study and an incubation temperature of $30{ }^{\circ} \mathrm{C}$ enabled higher ethanol concentrations for the industrial strains, compared to fermentations at $37{ }^{\circ} \mathrm{C}$. The amylolytic S. cerevisiae ER T12 and M2n T1 industrial strains, expressing the native $\alpha$-amylase and codon optimised glucoamylase from T. emersonii, represent a suitable drop-in CBP yeast substitute for the existing cold fermentation process as they produced in excess of $80 \%$ of the theoretical ethanol yield. Although high-temperature fermentations are more practical for industrial ethanol production, results showed that ethanol- and thermo-tolerance are limiting factors with regards to constructing a CBP yeast for the industrial production of bioethanol. Therefore, future studies aimed at ethanol and temperature tolerance yeast are required to engineer a robust amylolytic CBP strain that can ferment at higher temperatures.

\section{Methods}

\section{Media and cultivation conditions}

All chemicals were of analytical grade and were obtained from Merck (Darmstadt, Germany), unless otherwise stated. Escherichia coli DH5 $\alpha$ (Takara Bio Inc.) was used for vector propagation. The $E$. coli transformants were selected for on Luria-Bertani agar (Sigma-Aldrich, Steinheim, Germany), containing $100 \mu \mathrm{g} \mathrm{ml}^{-1}$ ampicillin and cultivated at $37{ }^{\circ} \mathrm{C}$ in Terrific Broth $\left(12 \mathrm{~g} \mathrm{l}^{-1}\right.$ tryptone, $24 \mathrm{~g} \mathrm{l}^{-1}$ yeast extract, $4 \mathrm{ml} \mathrm{l}^{-1}$ glycerol, $0.1 \mathrm{M}$ potassium phosphate buffer) containing $100 \mu \mathrm{g} \mathrm{ml}^{-1}$ ampicillin for selective pressure [43].

The $S$. cerevisiae parental strains were maintained on YPD agar plates ( $\mathrm{g} \mathrm{l}^{-1}: 10$ yeast extract, 20 peptone, 20 glucose and 15 agar) and S. cerevisiae Y294 transformants were selected for and maintained on $\mathrm{SC}^{-\mathrm{URA}}$ agar plates (6.7 $\mathrm{g} \mathrm{l}^{-1}$ yeast nitrogen base without amino acids (BD-Diagnostic Systems, Sparks, Maryland, USA), $20 \mathrm{~g} \mathrm{l}^{-1}$ glucose and $1.5 \mathrm{~g} \mathrm{l}^{-1}$ yeast synthetic drop-out medium supplements (Sigma-Aldrich, Steinheim, Germany) and $15 \mathrm{~g} \mathrm{l}^{-1}$ agar). S. cerevisiae strains were aerobically cultivated on a rotary shaker $(200 \mathrm{rpm})$ at $30{ }^{\circ} \mathrm{C}$, in $125 \mathrm{ml}$ Erlenmeyer flasks containing $20 \mathrm{ml}$ double strength $\mathrm{SC}^{-\mathrm{URA}}$ medium $\left(2 \times \mathrm{SC}^{-\mathrm{URA}}\right.$ containing $13.4 \mathrm{~g} \mathrm{l}^{-1}$ yeast nitrogen base without amino acids (BDDiagnostic Systems), $20 \mathrm{~g} \mathrm{l}^{-1}$ glucose and $3 \mathrm{~g} \mathrm{l}^{-1}$ yeast synthetic drop-out medium supplements). Fermentation media for the $S$. cerevisiae Y294 strains comprised of $2 \times \mathrm{SC}^{-\mathrm{URA}}$ containing $5 \mathrm{~g} \mathrm{l}^{-1}$ glucose and $200 \mathrm{~g} \mathrm{l}^{-1}$ raw corn starch (starch from corn-Sigma-Aldrich) [19, 24], whereas the medium for the industrial was YPD containing $5 \mathrm{~g} \mathrm{l}^{-1}$ glucose and $200 \mathrm{~g} \mathrm{l}^{-1}$ raw corn starch. Ampicillin $\left(100 \mu \mathrm{g} \mathrm{ml}^{-1}\right)$ and streptomycin $\left(50 \mu \mathrm{g} \mathrm{ml}^{-1}\right)$ were added to inhibit bacterial contamination. All cultures were inoculated to a concentration of $1 \times 10^{6}$ cells ml $\mathrm{ml}^{-1}$, unless stated otherwise.

The industrial $S$. cerevisiae transformants were selected for on SC-Ac plates (SC plates with $\left(\mathrm{NH}_{4}\right)_{2} \mathrm{SO}_{4}$ replaced by $0.6 \mathrm{~g} \mathrm{l}^{-1}$ acetamide and $\left.6.6 \mathrm{~g} \mathrm{l}^{-1} \mathrm{~K}_{2} \mathrm{SO}_{4}\right)$, containing $2 \%$ soluble corn starch. SC-Fac plates (SC media containing $2.3 \mathrm{~g} \mathrm{l}^{-1}$ fluoroacetamide) was used to induce the plasmid curing of the $\mathrm{yBBH} 1$-amdSYM episomal vector from the transformants. The $\mathrm{pH}$ for SC-Ac and SC-Fac plates was adjusted to 6.0 with $\mathrm{NAOH}$.

\section{Strains and plasmids}

The genotypes of the bacterial and yeast strains, as well as the plasmids used in this study are summarised in Table 1.

\section{DNA manipulations}

Standard protocols were followed for all DNA manipulations and E. coli transformations [43]. The enzymes used for restriction digests and ligations were purchased from Inqaba Biotec (Pretoria, South Africa) and used as recommended by the supplier. Digested DNA was eluted from $0.8 \%$ agarose gels using the Zymoclean ${ }^{\text {TM }}$ Gel DNA Recovery Kit (Zymo Research, California, USA). The $E N O 1_{\mathrm{P}}-\alpha$-amylase- $E N O 1_{\mathrm{T}}$ cassettes were amplified from the respective $\mathrm{yBBH} 1-\alpha$-amylase plasmids (Table 1) using yeast mediated ligation (YML) cassette primers ENOCASS-L and ENOCASS-R (Table 3) and cloned into the BglII site of the $\mathrm{yBBH} 1$-glucoamylase plasmid (Fig. 1a). The temA and temG_Opt gene cassettes (containing the ENO1 promoter and terminator) (Fig. 1c) were amplified through polymerase chain reaction (PCR) using the Delta-ENO1_Promoter-L and DeltaENO1_Terminator-R primers (Table 3), together with the yBBH1-TemA and yBBH1-TemG_Opt plasmids [20], respectively, as templates.

The $T E F 1_{\mathrm{P}}$-amdS-TEF1 $1_{\mathrm{T}}$ gene cassette was amplified from pUG-amdSYM through PCR using the amdSYMCas primers (Table 3 ) and cloned onto yBBH (digested with $B a m H I$ and $B g l \mathrm{II}$ to remove the $E N O 1_{\mathrm{P}}$ and $E N O 1_{\mathrm{T}}$ ) to yield plasmid yBBH1-amdSYM (Fig. 2b). The Ashbya gossypii TEF1 promoter regulated the expression of the acetamidase-encoding gene $(a m d S)$ for the selection of transformants on SC-Ac plates. The yBBH1amdSYM plasmid was retrieved from the $S$. cerevisiae Y294[amdSYM] strain and transformed into E. coli DH5 $\alpha$ to obtain a high concentration of plasmid DNA. Plasmid DNA was isolated using the High Pure Plasmid Isolation kit (Roche, Mannheim, Germany). DNA sequence verification was performed by the dideoxy chain termination method, with an ABI PRISM ${ }^{\mathrm{TM}} 3100$ Genetic Analyser (CAF, Stellenbosch University, South Africa). 


\section{Yeast transformations}

The S. cerevisiae Y294 strain was grown overnight in $5 \mathrm{ml}$ YPD broth and prepared according to [35] and transformed by means of electroporation using a Bio-Rad system (GenePluserXcell TM, Bio-Rad, Hercules, California, USA). After electroporation, $1 \mathrm{ml}$ of YPDS (YPD supplemented with $1 \mathrm{M}$ sorbitol) was immediately added to the cuvette. Cultures were incubated at $30{ }^{\circ} \mathrm{C}$ for $1 \mathrm{~h}$ prior to plating out onto $\mathrm{SC}^{-\mathrm{URA}}$ plates containing $2 \%$ soluble corn starch. Plates were incubated at $30{ }^{\circ} \mathrm{C}$ for $2-3$ days and then transferred to $4{ }^{\circ} \mathrm{C}$ for $24 \mathrm{~h}$ to allow the starch to precipitate.

Electro-competent industrial yeast cells were prepared in the same manner. For the transformation of industrial strains, amylase DNA (linear temA and temG_Opt ENO1 cassettes) were simultaneously transformed into the yeasts genomes using the $\mathrm{YBBH} 1$-amdSYM episomal vector, which contained the amdS selection marker (Fig. 2b). After electroporation, $1 \mathrm{ml}$ of YPDS was immediately added to the cuvettes and the cells were incubated at $30{ }^{\circ} \mathrm{C}$ for $3 \mathrm{~h}$. Transformants were selected for by plating the transformation mix on to $\mathrm{SC}-\mathrm{Ac}$ plates containing $2 \%$ starch [adapted from 17] and incubated at $30{ }^{\circ} \mathrm{C}$ for $24 \mathrm{~h}$. The integration of the linear DNA expression cassettes into the yeast genome was confirmed by PCR using gene-specific primers [20] and gene copy numbers were estimated using whole-genome sequencing.

\section{Genomic DNA extraction and library sequencing}

Genomic DNA was extracted from overnight yeast cultures according to PowerSoil ${ }^{\circledR}$ DNA Isolation Kit (MO BIO laboratories Inc., Carlsbad, CA USA). An additional cleaning step with Phenol: Chloroform: Isoamyl Alcohol (25: 24: 1) (Sigma-Aldrich) was performed before DNA isolation. Genomic libraries were generated using the TruSeq DNA PCR-Free Library Prep Kit (Illumina Inc., San Diego CA) and Covaris S2 (Woburn, MA) for a 550bp average fragment size. Libraries were loaded onto the flow cell provided in the NextSeq500 Reagent kit v2 (150 cycles) (Illumina Inc., San Diego CA) and sequenced on a NextSeq500 (Illumina Inc., San Diego CA) platform with a paired-end protocol and read lengths of $151 \mathrm{bp}$ at the CRIBI Biotechnology Center (Padova, Italy) to determine the copy number of the integrated temA and temG_Opt genes.

\section{Next-generation sequencing data analysis}

Raw reads were filtered using Trimmomatic version 0.33 (leading:35 trailing:35 sliding window:4:15 headcrop:35 minlen:100). The de novo assembly was performed using SPAdes version 3.9 (with option -k 21,33,55,77) [44]. High quality-filtered reads were aligned to assembled genomes using bowtie2 [45]. The assembled genomes were used to create a local database for BLAST analysis. All sequences of the integrated genes temA and temG_Opt and housekeeping genes (ACT1, ALG9, PGK1, TFC1) were used as queries for BLAST search against $S$. cerevisiae M2n T1 and ER T12 strains, independently. Copy numbers for integrated genes in each genome were determined by taking the ratio of average coverage of the integrated genes to average coverage of all scaffolds [46]. The coverage (the depth of sequencing) was calculated using BBMap in BBTools (http://sourceforge.net/projects/ bbmap). Moreover, the estimation of the integrated copy numbers was assessed considering the ratio between the average coverage of selected housekeeping genes for $S$. cerevisiae and the average coverage of the integrated genes. Statistically similar copy numbers were determined considering the ratio of integrated genes' average coverage to the average coverage of both all scaffolds and selected housekeeping genes. The genome assembly of S. cerevisiae M2n T1 and ER T12 was deposited at GenBank under the accession number SKCB00000000 and SKCC00000000, respectively. The versions described in this paper are version SKCB01000000 and SKCC01000000, respectively.

\section{Activity assays}

Industrial yeast transformants were cultured in $20 \mathrm{ml}$ $2 \times \mathrm{SC}^{- \text {URA }}$ media (inoculated at a concentration of $1 \times 10^{7}$ cells $\mathrm{ml}^{-1}$ ), in $125 \mathrm{ml}$ Erlenmeyer flasks with agitation at $200 \mathrm{rpm}$ and sampling at 24-h intervals. The assays for quantitative analysis of amylase activity were performed as described by [20]. The supernatant was used to colourimetrically assess (xMark ${ }^{\mathrm{TM}}$ Microplate Spectrophotometre, Bio-Rad, San Francisco, USA) the total extracellular amylase activity levels using the reducing sugar assay with glucose as standard [47]. The glucoamylase activities (released glucose) were determined according to the method described by Viktor et al. [19]. Enzymatic assays were performed in triplicate at $\mathrm{pH} 5$ and at 30 and $37{ }^{\circ} \mathrm{C}$, using $0.05 \mathrm{M}$ citrate buffer. Enzymatic activity was expressed as $\mathrm{U} \mathrm{ml}^{-1}$ supernatant, with one unit defined as the amount of enzyme required to release one $\mu$ mole of glucose per minute, under the described assay conditions. Soluble starch assays were performed using $0.2 \%$ soluble (autoclaved) corn starch, while raw starch assays were performed using $2 \%$ raw corn starch [48]. To determine glucose equivalents released from raw starch by engineered laboratory strains, the glucose and maltose concentrations were determined using HPLC, as described below under "Analytical methods and calculations". 


\section{Evaluation of mitotic stability of the industrial transformants}

To study mitotic stability of the obtained ER T12 and M2n T1 strains, the transformants were grown in sequential batch cultures using a method adapted from [48]. The strains were cultivated in non-selective YPD broth $(5 \mathrm{~mL})$ on a rotating wheel and transferred $(1 \% \mathrm{v}$ $\mathrm{v}^{-1}$ ) to fresh YPD after glucose depletion. After 250 generations, recombinant strains were plated onto YPD and incubated at $30{ }^{\circ} \mathrm{C}$ for $24 \mathrm{~h}$. Up to 100 colonies for each transformant were replicated onto $\mathrm{SC}^{\text {-URA }}$ plates containing $2 \%$ soluble corn starch. The stable transformants displayed hydrolytic activity on the starch plates after $24 \mathrm{~h}$.

\section{Marker recycling}

Plasmid curing was performed on the industrial recombinant strains according to [17]. The removal of the yBBH1amdSYM plasmid containing the acetamide marker was achieved by growing cells overnight in $5 \mathrm{ml}$ liquid YPD and transferring $20 \mu \mathrm{l}$ to a $125 \mathrm{ml}$ Erlenmeyer flask containing $10 \mathrm{ml} \mathrm{SC-Fac} \mathrm{media.} \mathrm{Marker-free} \mathrm{single} \mathrm{colonies}$ were obtained by plating $100 \mu \mathrm{l}$ of culture on SC-Fac solid media containing $2 \%$ soluble corn starch.

\section{Fermentations}

Saccharomyces cerevisiae Y294 precultures were cultured in $60 \mathrm{ml} 2 \times \mathrm{SC}^{-\mathrm{URA}}$ medium in $250 \mathrm{ml}$ Erlenmeyer flasks, whereas industrial S. cerevisiae ER and M2n precultures were cultivated similarly in YPD medium, for small scale fermentations. Flasks were incubated at $30{ }^{\circ} \mathrm{C}$ with agitation at $200 \mathrm{rpm}$. Fermentations with the $S$. cerevisiae Y294 strains were performed at an incubation temperature of $30{ }^{\circ} \mathrm{C}$ according to [24], while fermentations with the industrial $S$. cerevisiae yeasts were performed at both $30{ }^{\circ} \mathrm{C}$ and $37^{\circ} \mathrm{C}$ in YPD medium (containing $5 \mathrm{~g} \mathrm{l}^{-1}$ glucose) with a $10 \%$ inoculum. The substrate loading for all fermentations was $200 \mathrm{~g} \mathrm{l}^{-1}$ corn starch (183.3 $\mathrm{g} \mathrm{l}^{-1}$ dry weight). The exogenous GSHE cocktail used to supplement the fermentation process was STARGEN $002^{\mathrm{TM}}$ genencor.com) and used according to the manufacturers instructions. STARGEN $002^{\mathrm{TM}}$ contains Aspergillus kawachii $\alpha$-amylase expressed in Trichoderma reesei and a glucoamylase from $T$. reesei that work synergistically to hydrolyse granular starch to glucose [37].

\section{Bioreactor fermentations}

Saccharomyces cerevisiae Y294 precultures were cultivated in $120 \mathrm{ml} 2 \times \mathrm{SC}^{-\mathrm{URA}}$ media in $500 \mathrm{ml}$ Erlenmeyer flasks at $30{ }^{\circ} \mathrm{C}$ with agitation at $200 \mathrm{rpm}$. Bioreactor fermentations were performed in a 2-l MultiGen Bioreactor (New Brunswick Scientific Corporation, New Jersey, USA) containing $2 \times \mathrm{SC}^{-\mathrm{URA}}$ media supplemented with $200 \mathrm{~g} \mathrm{l}^{-1}$ raw corn starch and $5 \mathrm{~g} \mathrm{l}^{-1}$ glucose as carbohydrate source. A $10 \%\left(\mathrm{v} \mathrm{v}^{-1}\right)$ inoculum was used in a total working volume of 1-l. Fermentations were carried out at incubation temperatures of $26^{\circ} \mathrm{C}$ and $30^{\circ} \mathrm{C}$, with stirring at $300 \mathrm{rpm}$ and daily sampling through a designated sampling port. All fermentation experiments were performed in triplicate.

\section{Analytical methods and calculations}

Ethanol, glucose, maltose, glycerol and acetic acid concentrations were quantified using High-performance liquid chromatography (HPLC) according to [24]. The theoretical $\mathrm{CO}_{2}$ yields were calculated according to [16]. The glucose equivalent is defined as the mass of glucose resulting from the complete hydrolysis of starch, i.e. 1.11 grams of glucose per gram of starch. The available carbon (mol carbon in $100 \%$ hydrolysed substrate) was calculated based on the available glucose (glucose equivalent used was $208.5 \mathrm{~g} \mathrm{l}^{-1}$, therefore, total mol carbon equals 6.95). The estimated carbon conversion is defined as the percentage starch converted on a mol carbon basis (Eq. 1). The estimated carbon conversion (as a percentage) was calculated from ethanol, glucose, maltose, glycerol, acetic acid and $\mathrm{CO}_{2}$ concentrations using the following equation:

Equation 1: Estimated carbon conversion (\%)

$$
\frac{\left[\left(\text { maltose } \times \frac{12}{342}\right)+\left(\text { glucose } \times \frac{6}{180}\right)+\left(\text { glycerol } \times \frac{3}{92}\right)+\left(\text { acetic acid } \times \frac{2}{60}\right)+\left(\text { carbon dioxide } \times \frac{1}{44}\right)\right]}{\text { mol carbon }} \times 100
$$

mol carbon

(referred to as GSHE in this study) obtained from Dupont Industrial Biosciences (Palo Alto, California, USA) with an activity minimum of $570 \mathrm{GAU} \mathrm{gm}^{-1}$ (http://www.
The ethanol yield (\% of the theoretical yield) was calculated as the amount of ethanol produced per gram of available glucose. The ethanol productivity was 
calculated based on ethanol concentration produced per $\mathrm{h}\left(\mathrm{g} \mathrm{l}^{-1} \mathrm{~h}^{-1}\right)$.

\section{Statistical analysis \\ Measurements represent the mean of three repeats. Data was analysed using the Student's $t$ test to determine sig- nificant differences between recombinant yeast strains.}

\begin{abstract}
Abbreviations
bp: base pair; CBP: consolidated bioprocessing; cDNA: copy-deoxyribonucleic acid; DDGS: distiller's dried grains with solubles; DNA: deoxyribonucleic acid; GSHE: granular starch hydrolysing enzyme; HPLC: high performance liquid chromatography; PCR: polymerase chain reaction; SDS-PAGE: sodium dodecyl sulphate polyacrylamide gel electrophoresis; SC: synthetic complete; SC ${ }^{-U R A}$ : synthetic complete lacking uracil; SSF: simultaneous saccharification and fermentation; YPD: yeast extract, peptone, dextrose; YML: yeast mediated ligation.
\end{abstract}

\section{Acknowledgements}

The authors would like to thank Mrs Lisa Warburg for her assistance with HPLC analysis, as well as Dr Laura Treu (Padova University) for her assistance with the analysis of sequencing data.

\section{Authors' contributions}

RAC, SHR and WHVZ participated in the design of the study. RAC performed the experimental work relating to yeast strain construction and fermentations, as well as drafted the manuscript. LF performed the genomic DNA extraction and library sequencing and analysed the next-generation sequencing data. All the authors read and commented on the draft manuscript. RAC, SHR and WHVZ are co-inventors on patent applications related to the present work. All authors read and approved the final manuscript.

\section{Funding}

This work was supported by the National Research Foundation (NRF) for financial support to the Chair of Energy Research: Biofuels and other clean alternative fuels (NRF Grant 86423) and by Padova University (Grant DOR1824847/18). RAC postdoctoral fellowship has been funded by the Claude Leon Foundation.

\section{Availability of data and materials}

The datasets generated during the current study are available in the GenBank repository, accession numbers provided in text.

Ethics approval and consent to participate

Not applicable.

\section{Consent for publication}

Not applicable.

\section{Competing interests}

The authors declare that they have no competing interests.

\section{Author details}

${ }^{1}$ Department of Microbiology, Stellenbosch University, Private Bag X1, Matieland 7602, South Africa. ${ }^{2}$ Department of Agronomy Food Natural resources Animals and Environment (DAFNAE), Università di Padova, Agripolis, Viale dell'Università 16, 35020 Legnaro, Padova, Italy.

Received: 12 March 2019 Accepted: 8 August 2019

Published online: 20 August 2019

\section{References}

1. Mobini-Dehkordi M, Javan FA. Application of alpha-amylase biotechnology. J Biol Today's World. 2012;1:15-20.
2. Nigam $P$, Singh D. Enzyme and microbial systems involved in starch processing. Enzyme Microb Technol. 1995;17:770-8.

3. Pandey A, Nigam P, Soccol CR, Soccol VT, Singh D, Mohan R. Advances in microbial amylases. Biotechnol Appl Biochem. 2000;31:135-52.

4. Szymanowska-Powałowska D, Lewandowicz G, Kubiak P, Błaszczak W. Stability of the process of simultaneous saccharification and fermentation of corn flour. The effect of structural changes of starch by stillage recycling and scaling up of the process. Fuel. 2014;119:328-34.

5. Robertson GH, Wong DW, Lee CC, Wagschal K, Smith MR, Orts WJ. Native or raw starch digestion: a key step in energy efficient biorefining of grain. J Agric Food Chem. 2006;54:353-65.

6. Nkomba EY, van Rensburg E, Chimphango AF, Görgens JF. The influence of sorghum grain decortication on bioethanol production and quality of the distillers' dried grains with solubles using cold and conventional warm starch processing. Bioresour Technol. 2016;203:181-9.

7. Brehmer B, Bals B, Sanders J, Dale B. Improving the corn-ethanol industry: studying protein separation techniques to obtain higher value-added product options for distillers grains. Biotechnol Bioeng. 2008;101:49-61.

8. Van Zyl WH, Bloom M, Viktor MJ. Engineering yeasts for raw starch conversion. Appl Microbiol Biotechnol. 2012;95:1377-88.

9. Salehi Jouzani G, Taherzadeh MJ. Advances in consolidated bioprocessing systems for bioethanol and butanol production from biomass: a comprehensive review. Biofuel Res J. 2015;5:152-95.

10. Den Haan R, van Rensburg E, Rose SH, Görgens J, van Zyl WH. Progress and challenges in the engineering of non-cellulolytic microorganisms for consolidated bioprocessing. Curr Opin Biotechnol. 2015;33:32-8.

11. Den Haan R, Kroukamp H, Mert MJ, Bloom M, Gorgens JF, van Zyl WH. Engineering Saccharomyces cerevisiae for next generation ethanol production. J Chem Technol Biotechnol. 2013;88:983-91.

12. Görgens JF, Bressler DC, van Rensburg E. Engineering Saccharomyces cerevisiae for direct conversion of raw, uncooked or granular starch to ethanol. Crit Rev Biotechnol. 2015;35:369-91.

13. Walker GM, Walker RSK. Enhancing yeast alcoholic fermentations. Adv Appl Microbiol. 2018;105:87-129.

14. Kumar D, Singh V. Dry-grind processing using amylase corn and superior yeast to reduce the exogenous enzyme requirements in bioethanol production. Biotechnol Biofuels. 2016;9:228.

15. Demeke MM, Dietz H, Li Y, Foulquié-Moreno MR, Mutturi S, Deprez S, Den Abt T, Bonini BM, Liden G, Dumortier F, Verplaetse A, Boles E, Thevelein JM. Development of a D-xylose fermenting and inhibitor tolerant industrial Saccharomyces cerevisiae strain with high performance in lignocellulose hydrolysates using metabolic and evolutionary engineering. Biotechnol Biofuels. 2013;6:89.

16. Favaro L, Viktor M, Rose S, Viljoen-Bloom M, van Zyl W, Basaglia M, Cagnin $L$, Casella S. Consolidated bioprocessing of starchy substrates into ethanol by industrial Saccharomyces cerevisiae strains secreting fungal amylases. Biotechnol Bioeng. 2015;112:1751-60.

17. Solis-Escalante D, Kuijpers NGA, Bongaerts N, Bolat I, Bosman L, Pronk JT, Daran JM, Daran-Lapujade P. amdSYM, a new dominant recyclable marker cassette for Saccharomyces cerevisiae. FEMS Yeast Res. 2013;13:126-39.

18. Hahn-Hägerdal B, Galbe M, Gorwa-Grauslund MF, Lidén G, Zacchi G. Bio-ethanol - the fuel of tomorrow from the residues of today. Trends Biotechnol. 2006:24:549-56.

19. Viktor MJ, Rose SH, van Zyl WH, Viljoen-Bloom M. Raw starch conversion by Saccharomyces cerevisiae expressing Aspergillus tubingensis amylases. Biotechnol Biofuels. 2013;6:167

20. Cripwell RA, Rose SH, Viljoen-Bloom M, Van Zyl WH. Improved raw starch amylase production by Saccharomyces cerevisiae using codon optimisation strategies. FEMS Yeast Res. 2019;19:foy127.

21. Henderson CM, Block DE. Examining the role of membrane lipid composition in determining the ethanol tolerance of Saccharomyces cerevisiae. Appl Environ Microbiol. 2014:80:2966-72.

22. Henderson CM, Zeno WF, Lerno LA, Longo ML, Block DE. Fermentation temperature modulates phosphatidylethanolamine and phosphatidylinositol levels in the cell membrane of Saccharomyces cerevisiae. Appl Environ Microbiol. 2013:79:5345-56.

23. Woo JM, Yang KM, Kim SU, Blank LM, Park JB. High temperature stimulates acetic acid accumulation and enhances the growth inhibition and ethanol production by Saccharomyces cerevisiae under fermenting conditions. Appl Microbiol Biotechnol. 2014;98:6085-94 
24. Sakwa L, Cripwell RA, Rose SH, Viljoen-Bloom M. Consolidated bioprocessing of raw starch with Saccharomyces cerevisiae strains expressing fungal alpha-amylase and glucoamylase combinations. FEMS Yeast Res. 2018;18:foy085.

25. Schmidt FR. Optimization and scale up of industrial fermentation processes. Appl Microbiol Biotechnol. 2005;68:425-35.

26. Favaro L, Basaglia M, Trento A, van Rensburg E, García-Aparicio M, van Zyl $\mathrm{WH}$, Casella S. Exploring grape marc as trove for new thermotolerant and inhibitor-tolerant Saccharomyces cerevisiae strains for second-generation bioethanol production. Biotechnol Biofuels. 2013;6:168.

27. Khanahmadi M, Roostaazad R, Mitchell DA, Miranzadeh M, Bozorgmehri $\mathrm{R}$, Safekordi A. Bed moisture estimation by monitoring of air stream temperature rise in packed-bed solid-state fermentation. Chem Eng Sci. 2016;61:5654-63.

28. Abdel-Banat BMA, Hoshida H, Ano A, Nonklang S, Akada R. Hightemperature fermentation: how can processes for ethanol production at high temperatures become superior to the traditional process using mesophilic yeast? Appl Microbiol Biotechnol. 2010;85:861-7.

29. Banat IM, Nigam P, Singh D, Marchant R, McHale AP. Ethanol production at elevated temperatures and alcohol concentrations: part I-yeasts in general. World J Microbiol Biotechnol. 1998;14:809-21.

30. Mukhtar K, Asgher M, Afghan S, Hussain K, Zia-UI-Hussnain S. Comparative study on two commercial strains of Saccharomyces cerevisiae for optimum ethanol production on industrial scale. J Biomed Biotechnol. 2010;210:419586

31. Celińska E, Borkowska M, Białas W. Evaluation of a recombinant insectderived amylase performance in simultaneous saccharification and fermentation process with industrial yeasts. Appl Microbiol Biotechnol. 2016;100:2693-707

32. Da Silva NA, Srikrishnan S. Introduction and expression of genes for metabolic engineering applications in Saccharomyces cerevisiae. FEMS Yeast Res. 2012;12:197-214

33. Cagnin L, Favaro L, Gronchi N, Rose SH, Basaglia M, van Zyl, WH, Casella S. Comparing laboratory and industrial yeast platforms for the direct conversion of cellobiose into ethanol under simulated industrial conditions. FEMS Yeast Res. 2019, foz018 (in press).

34. Kavšček M, Stražar M, Curk T, Natter K, Petrovič U. Yeast as a cell factory: current state and perspectives. Microb Cell Fact. 2015;14:94.

35. Cho KM, Yoo YJ, Kang HS. $\delta$-Integration of endo/exoglucanase and $\beta$-glucosidase genes into the yeast chromosomes for direct conversion of cellulose to ethanol. Enzyme Microb Technol. 1999;25:23-30.

36. Cinelli BA, Castilho LR, Freire DMG, Castro AM. A brief review on the emerging technology of ethanol production by cold hydrolysis of raw starch. Fuel. 2015;150:721-9.

37. DuPont. Granular starch hydrolyzing enzyme for ethanol production, 2012. p. 2-3.
38. Gronchi N, Favaro L, Cagnin L, Brojanigo S, Pizzocchero V, Basaglia M, Casella S. Novel yeast strains for the efficient saccharification and fermentation of starchy by-products to bioethanol. Energies. 2019;12:714.

39. Wallace-Salinas V, Gorwa-Grauslund MF. Adaptive evolution of an industrial strain of Saccharomyces cerevisiae for combined tolerance to inhibitors and temperature. Biotechnol Biofuels. 2013;6:151.

40. Stovicek V, Borja GM, Forster J, Borodina I. EasyClone 2.0: expanded toolkit of integrative vectors for stable gene expression in industrial Saccharomyces cerevisiae strains. J Ind Microbiol Biotechnol. 2015;42:1519-31.

41. Yamakawa S, Yamada R, Tanaka T, Ogino C, Kondo A. Repeated fermentation from raw starch using Saccharomyces cerevisiae displaying both glucoamylase and a-amylase. Enzyme Microb Technol. 2012;50:343-7.

42. Wong D, Batt Throne SB, Robertson GH, Lee CC, Wagschal KC. Chromosomal integration of both an alpha-amylase and a glucoamylase gene in Saccharomyces cerevisiae for starch conversion. Ind Biotechnol. 2010;6:112-9.

43. Sambrook J, Fritsch EF, Maniatis T. Molecular cloning: A laboratory manual. Cold Spring Harbor: Cold Spring Harbor Laboratory Press; 1989. p. 34.

44. Bankevich A, Nurk S, Antipov D, Gurevich AA, Dvorkin M, Kulikov AS, Lesin MV, Nikolensko SI, Pham S, Prjibelski AD, Pyshkin AV, Sirotkin AV, Vyahhi N, Tesler N, Alekseyev MA, Pevzneret PA. SPAdes: a new genome assembly algorithm and its applications to single-cell sequencing. J Comput Biol. 2012;19:455-77.

45. Langmead B, Salzberg LS. Fast gapped-read alignment with Bowtie 2. Nat Methods. 2012;9:357-9.

46. Maury J, Germann SM, Jacobsen SAB, Jensen NB, Kildegaard KR, Herrgård MJ, Schneider K, Koza A, Forster J, Nielsen J, Borodina I. EasyCloneMulti: a set of vectors for simultaneous and multiple genomic integrations in Saccharomyces cerevisiae. PLoS ONE. 2016;11:e0150394.

47. Miller GL. Use of dinitrosalicyclic acid reagent for determination of reducing sugars. Anal Chem. 1959;31:426-8.

48. Favaro L, Jooste T, Basaglia M, Rose SH, Saayman M, Göorgens JF, Casella S, van Zyl WH. Codon-optimized glucoamylase sGAl of Aspergillus awamori improves starch utilization in an industrial yeast. Appl Microbiol Biotechnol. 2012;95:957-68.

49. Njokweni A, Rose SH, van Zyl WH. Fungal $\beta$-glucosidase expression in Saccharomyces cerevisiae. J Mol Microbiol Biotechnol. 2012;39:1445-52.

\section{Publisher's Note}

Springer Nature remains neutral with regard to jurisdictional claims in published maps and institutional affiliations.
Ready to submit your research? Choose BMC and benefit from:

- fast, convenient online submission

- thorough peer review by experienced researchers in your field

- rapid publication on acceptance

- support for research data, including large and complex data types

- gold Open Access which fosters wider collaboration and increased citations

- maximum visibility for your research: over 100M website views per year

At BMC, research is always in progress.

Learn more biomedcentral.com/submissions 